\title{
Influence Factors Internal and External Factors Motivation and Performance of Employees: Do not Stay Civil Service Policy Unit
}

\author{
Pandi Afandi ${ }^{1} \&$ Helwen Heri ${ }^{1}$ \\ ${ }^{1}$ Graduate Program Master of Management, University Lancang Kuning Pekanbaru Riau, Indonesia \\ Correspondence: Priyono, Graduate Program Master of Management, University Bina Darma Indonesia. Tel: \\ 62-812-1697-4878. E-mail: priyono.unu_sidoarjo@yahoo.com
}

Received: February 29, 2016

Accepted: March 11, 2016

Online Published: May 25, 2016

doi:10.5539/ijef.v8n6p258

URL: http://dx.doi.org/10.5539/ijef.v8n6p258

\begin{abstract}
This research of background that directional and effective use of labor represent key toward the make-up of officer performance so that need to District Police Public Service head to make a manage the members always enthusiastic in working and having positive in executing work.Effort roomates can be a head-to Increase the activity spirit of enthusiasm, that is by giving good motivation and job performance.Intention of this research is to know and Analyzed do internal factors variable, external factor variable and motivation have influenced the which significantly either through partial and Also simultaneously to job performance officer, and Also from internal factors variable, external factor variable and motivation is the which most having an effect on the which to job performance officer.

This research is a survey verification sampling on 200 people from 236 respondend contract employee population of District Police Public Service Riau Province.This research represent research highlighting clarification relation between research variables and test hypotheses have been Formulated Previously roomates.Hereinafter technique intake of sample is used by population technique, where samples taken pursuant to SEM formula for 25 manifest variables using a minimum of 200 samples.Technique Analyzed using descriptive and quantitative analysis by applying the method of Structural Equation Modelling (SEM) with Analysis of Moment Structures (AMOS) programe.
\end{abstract}

Keywords: internal factor, external factor, motivation and performance

\section{Introduction}

Municipal Police Units, abbreviated municipal police, is the Local Government in maintaining peace and public order and enforce regional regulations. Municipal police is an area shaped device Technical Institute. Municipal police may be domiciled in the Region. Provincial and District/City. In Provincial, Municipal Police Force chaired by the Chief under and responsible to the Governor through the Regional Secretary. In District/City, Civil Service Police Unit led by head under and responsible to the Regent/Mayor through the Regional Secretary. Organization and administration of the Civil Service Police Unit assigned to the regional regulations.

In the Civil Service Police Unit Riau Province are civil servants and clerks are not fixed. For civil servants they were employees of the civil service police unit, while the Temporary staff are aid workers, civil service police abbreviated to help Police Civil Service duty to help the work of the Servants of the Civil Service Police Unit.

So that member has the passion and excitement in the work it needs a good performance management, because with the performance of the management members feel will be noticed and have an incentive to carry out the task with gusto. So that members can work well and provide achievement for the work unit, the member shall be given the motivation, for the leadership of the civil service municipal police must consider how to keep the members are always passionate in your work and have a positive attitude in performing the task.

Data obtained by researchers from the Division of Administration Civil Service Police Unit Riau province on employee absenteeism is not permanent Civil Service Police Unit Riau Province.

The details are: in 2009 an employee who was not present as many as 209 people (11.5\%). In 2011 employees not attended as many as 105 people (6\%). In 2012 employees who not attended as many as 110 people (6.1\%). 2013 employees not attended by 135 people (7.5\%). 2014 employees who did not attend as many as 150 people (8.3\%). 2015 employees not attended by 178 people $(10.1 \%)$. 
From the above data we can conclude that the rate of absenteeism in the presence of a police unit of the Civil Service is going up - down.

According to Big Indonesian Dictionary (2010), the performance is something that is achieved, demonstrated achievement, ability to work. Mean while, according Wirawan (2009), the performance is the output produced by functions or indicators of a job or a profession in a given time. Performance refers to the achievement of the employees for a given task Marifah (2009).

Etymologically, the word comes from the performance of work performance. As stated by Mangkunagara (2005) in Trinaningsih (2009) that the term performance is derived from the word job performance or the actual performance (performance or achievements actually reached someone) that the work in quality and quantity is achieved by an employee in performing their duties in accordance with the responsibility given to him. Performance can be divided into two, namely the performance of the individual and organizational performance. Individual performance is the employee's performance in terms of both quality and quantity based on the standard of work that has been determined, while the performance of the organization is a combination of individual performance with the performance of the group (Mangkunagara, 2005) in (Trinaningsih, 2009).

Motivation is an impulse that drives a person to work harder to achieve goals. With the provision of a good motivation to be able to solve problems that commonly occur in a person such as a low quality of care and discipline in the workplace. The importance of motivation is a cause, distribute, and support of human behavior so he would work diligently and enthusiastically to achieve optimal results. Motivation questioned how direct the power and potential of subordinates, to cooperate productively managed to achieve and realize its intended purpose.

The term motivation comes from the Latin word "movere" which means encouragement or move by Danang Sunyoto, (2013, p. 1), Motivation is a state that drives the desire of individuals to conduct - certain activities to achieve his wish. Motivation questioned how direct power and potential to work the objectives set (Malayu SP Hasibuan, 2009, p. 141).

According to Vroom in Ngalim Purwanto (2008, p. 72), motivation refers to a process of influencing individual choices of the various forms of activity are desired. Then John P. Campbell, et al suggested that the motivation include in it the direction or goal behavior, the strength of the response, and the persistence of behavior. In addition, the term covers a range of concepts impulse, needs, stimulation, reward, reinforcement, provisions goal, hope, and so forth.

According to Sondra P. Siagian (2009, p. 294) motivation is influenced by several factors, both internal and external.

Which included internal factors are:

1) Perception of oneself;

2) Self-esteem;

3) Personal Expectations;

4) Salary;

5) Interest;

6) Job satisfaction;

7) The achievement of the work produced;

While external fakor that affect one's motivation, among others:

1) The type and nature of work;

2) working group where someone joins;

3) organization where people work;

4) The situation of the working environment.

\subsection{Formulation of the Problem}

Based on the background mentioned above, the authors formulate the problem in this research are: (1) How would you describe the performance, motivation, internal factors and external factors; (2) the extent of internal factors and external factors on the motivation and performance of partially and simultaneously, for temporary staff Civil Service Police Unit. 


\subsection{Research Purposes}

The objectives of this study were: (1) For a description of the performance, motivation, internal factors and external factors; (2) To find the influence of internal and external factors on the motivation and work performance partially and simultaneously, for temporary staff Civil Service Police Unit.

\section{Research Methods}

The scope of this study is to examine the influence of internal factors, external factors on the motivation and performance of employees are not permanent Civil Service Police Unit Riau Province. Unit analysis of temporary employees in the Civil Service Police Unit Riau Province. Verificative research type descriptive research, with 200 respondents from a population of 236 people.

Data collection in this study conducted by survey (survey method). Sample of respondents with a probability sampling technique that gives equal opportunity for every member of the population to be selected into the sample. (Arikunto, 2007). The primary data obtained through interviews using a structured questionnaire and in-depth interviews (in-depth interviews) to the selected respondents. Secondary data were obtained through library research on various references such as textbooks, annual reports, the publication of official documents, journals, magazines, and relevant scientific articles.

Testing Data do with the validity and reliability using the application AMOS on the test Confirmatory Factor Analysis (Test CFA). Based on test validity of research instruments for variable internal factors, external factors and motivation of employees, shows that the whole statement is valid to measure each dimension / indicator each variable. the analytical method used is descriptive analysis and quantitative analysis. Application program in this research using an analysis tool by Structural Equation Modeling (SEM) program of Analysis of Moment Structures (AMOS) for the following reasons:

Amos has advantages compared to other software that includes:

a) The program can perform analysis using data from several populations at once.

b) Can handle missing data as well, namely by making an estimate based on information maximum likelihood perfect and not simply rely on existing methods, namely listwise, pairwise deletion, or mean imputation.

c) to make the average estimate for exogenous variables and intercepts in regression equations.

d) Amos can also make bootstrapped standard errors and confidence intervals are present in all of the estimated parameters, the sample average, variance, covariance and correlation.

e) to make percentile intervals and bias-corrected percentile intervals

f) Plural models can be adjusted using a single analysis.

g) to examine every pair of models where one model is obtained by restricting the parameters of other models.

h) to make a report several statistics which to do the comparison for these models.

i) Amos also provides univariate normality test for each variable were observed and also testing multivariate normality and can detect ouliers.

j) Amos can be understood as a path diagram shows the model specification and parameter estimates graphically in the diagram model lines. Diagrams lane is used as the model specification and the drawings of the path diagram can be imported into Word program.

The research variables is an abstract concept that can be measured (observed variables), but there is also an abstract concept that can not be measured directly (unobserved variables).

This study is intended to test the multidimensionality of the construct that consists of four variables: Performance (KJA), Motivation (MOT), the internal factor (FIN) and External Factor (FEX).

Conceptualization of the model can be seen in Figure 1 below: 


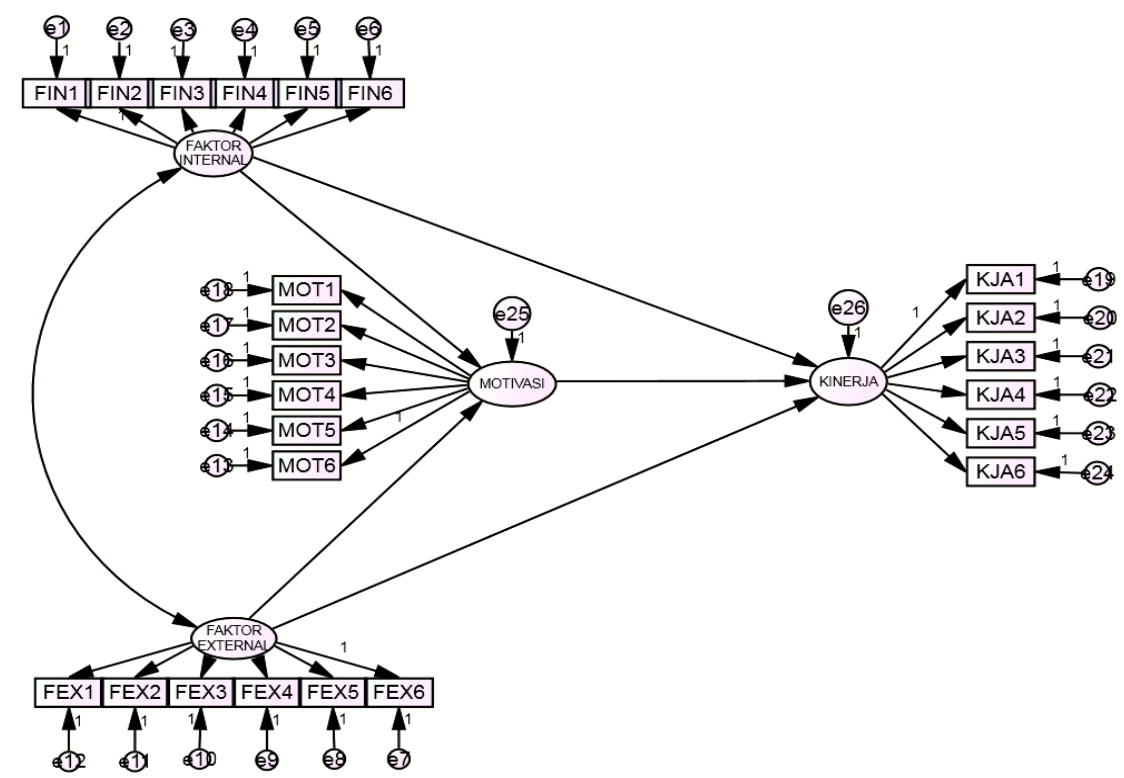

Figure 1. Conceptual model

Caption:

Performance: The dependent latent variable that consists of six manifest variables (KJA1, KJA2, KJA3, KJA4, KJA5 and KJA6). Motivation: Variebel independent latent consisting of 6 manifest variables (MOT1, MOT2, MOT3, MOT4, MOT5 and MOT6). Internal factors: independent latent variables consisting of 6 manifest variables (FIN1, FIN2, FIN3, FIN4, FIN5 and FIN6). External factors: independent latent variables consisting of 6 manifest variables (FEX1, FEX2, FEX3, FEX4, FEX5 and FEX6).

\subsection{Research Hypothesis}

Based on a literature review and conceptualization models above, then the hypothesis in this study are as follows:

1). There is a direct influence of variable internal factors on motivation.

2). There is a direct influence of external factors on the motivation variable.

3). There is a direct influence of internal factors and external factors on the motivation.

4). There is a direct influence of internal factors on the performance variables.

5). There is a direct influence of external factors on the performance variables.

6). There is a direct influence of motivational variables on performance.

7). There is a direct influence of internal factors and external factors on performance.

8). There is a direct influence of internal factors, external factors and motivation to performance.

9). There is an indirect effect of internal factors variable to variable performance through motivation variable.

10). There indirect influence of external factors variable to variable performance through motivation variable.

11). There indirect influence of variable factors internal and external factors to variable performance through motivation variable.

Table 1. Relationship variables, dimensions and indicators

\begin{tabular}{ccl}
\hline variable & dimension & Indicator \\
\hline & FI.1 & FIN.1.1.like jobs \\
X1 & Hope & FIN.1.2.price himself lifted \\
& FIN.1.3.hope granted \\
Internal factors & FI.2 & FIN.2.1.salary accordance with the rules \\
(Siagan, 2009) & Wage & FIN.2.2.salary have sufficient \\
& & additional FIN.2.3.Incentive
\end{tabular}




\begin{tabular}{|c|c|c|}
\hline \multirow{6}{*}{$\begin{array}{c}\mathrm{X} 2 \\
\text { External factors } \\
\text { (Siagan, 2009) }\end{array}$} & \multirow{3}{*}{$\begin{array}{c}\text { FE.1 } \\
\text { Work environment }\end{array}$} & FEX.1.1.type appropriate job \\
\hline & & FEX.1.2.relationship work \\
\hline & & FEX.1.3.Structure organizations \\
\hline & \multirow{3}{*}{$\begin{array}{l}\text { FE. } 2 \\
\text { Aim }\end{array}$} & FEX.2.1.reach desires \\
\hline & & FEX.2.2. achievement work achieved \\
\hline & & FEX.2.3.satisfaction work \\
\hline \multirow{6}{*}{$\begin{array}{c}\text { Y } \\
\text { Motivation } \\
\text { (Purwanto, 2006) }\end{array}$} & \multirow{3}{*}{$\begin{array}{c}\text { M1 } \\
\text { unmet needs }\end{array}$} & MOT.1.1.leadership give morale \\
\hline & & MOT.1.2.fullfilled needs of employees \\
\hline & & MOT.1.3.salary which complies \\
\hline & & MOT.2.1.ameneties work complete \\
\hline & Wherk otmocnero & MOT.2.2.atmosphere conducive working \\
\hline & work atmospnere & MOT.2.1.appreciation work \\
\hline \multirow{6}{*}{$\begin{array}{c}\mathrm{Z} \\
\text { performance } \\
\text { (Wirawan, 2015) }\end{array}$} & \multirow{3}{*}{$\begin{array}{c}\text { K1 } \\
\text { Work result }\end{array}$} & KJA1.1.quantity work \\
\hline & & KJA1.2.quality work \\
\hline & & KJA1.3.Efficient in task \\
\hline & \multirow{3}{*}{$\begin{array}{c}\text { K2 } \\
\text { Work behavior }\end{array}$} & KJA2.1.Discipline work \\
\hline & & KJA2.2.Initiatife \\
\hline & & KJA2.3.accuracy \\
\hline
\end{tabular}

As for the track diagram above, consists of three sub-structures, for more details can be seen on the track following equation:

Equation substructures to one:

$$
Y=b_{1} X_{1}+b_{2} X_{2}+\varepsilon_{1}
$$

Equation substructures to two:

\section{Results and Discussion}

\subsection{Descriptive Factors Internal, External Factors, Motivation and Employee Performance}

Internal factors has significance for employees, two dimensions that expectation (3 indicators) and goals (3 indicators) each having a high enough score in the category.

External factors has significance for employees, ie two-dimensional work environment ( 3 indicators) and wages (3 indicators) each having a high enough score in the category.

Motivation has significance for employees in organizations, two dimensions are unmet ( 3 indicators) and working conditions ( 3 indicators) each having a high enough score in the category.

Employee performance has significance for employees in organizations, two dimensions that work (3 indicators) and work behavior ( 3 indicators) each having a high enough score in the category.

This verification analysis aims to identify and examine the influence of internal factors and external factors on the motivation and performance of non-permanent employees. This test is to determine the empirical truth of the response of non-permanent employees of the Civil Service Police Unit Riau Province.

\subsection{Analysis of Measurement Model SEM (Outer Model)}

This study consists of 4 (four) latent variables; Performance (KJ), Motivation (MOT), the internal factor (FIN), External Factors (FEX). Each latent variable has six (6) indicators, so overall there are 24 (twenty four) indicators or variables manifest and latent variables with first order factor. The overall results when processed using a component-based SEM with sorfware Analysis of Moment Structures (AMOS) can be checked as shown in Figure 2 below. 


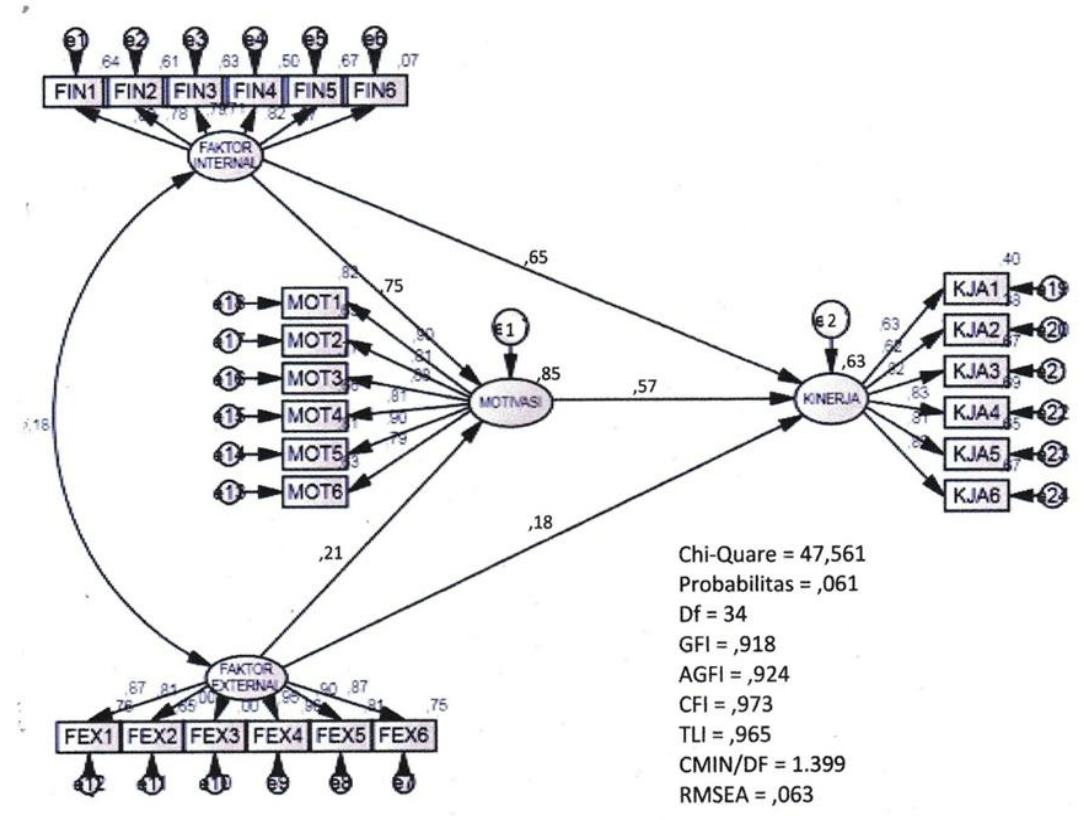

Figure 2. Sorfware analysis of moment structures (AMOS)

The above diagram describes the flow of research results, which consist of the amount of correlation values, the value of each path coefficient $(\rho)$, the coefficient of determination $\left(\mathrm{R}^{2)}\right.$ and the value of epsilon $(\varepsilon)$.

3.3 Results of Direct Impact Analysis (PL), Effect of Indirect (PTL), and Impact Total (PT)

1). The direct effect of $X 1$ to $Y=0,753$

2). The direct effect of $X 2$ to $Y=0.214$

3). The direct effect of $\mathrm{X} 1$ and $\mathrm{X} 2$ to $\mathrm{Y}=0.851$

4). The direct effect of $X 1$ to $Z=0.654$

5). The direct effect $X 2$ to $Z=0.181$

6). The direct effect $X 1$ and $X 2$ to $Z=0.632$

7). The direct effect $Y$ to $Z=0.571$

8). The direct effect of $X 1, X 2$ and $Y$ to $Z=0.967$

9). The indirect effect $X 1$ to $Z$ with $Y=0.429$

10). Indirect effect $X 2$ to $Z$ with $Y=0.122$

11). The indirect effect $X 1$ and $X 2$ to $Z$ with $Y=0.552$

Table 2. Summary of effects of direct, indirect, and total effect

\begin{tabular}{|c|c|c|c|}
\hline \multirow{2}{*}{ Variable } & \multicolumn{2}{|c|}{ Influence } & \multirow{2}{*}{ Total Influence } \\
\hline & Direct Impact & Indirect Through Y & \\
\hline $\mathrm{X} 1$ to $\mathrm{Y}$ & 0,753 & - & 0,753 \\
\hline $\mathrm{X} 2$ to $\mathrm{Y}$ & 0.214 & - & 0.214 \\
\hline $\mathrm{X} 1$ to $\mathrm{Z}$ & .654 & .429 & 1.083 \\
\hline $\mathrm{X} 2$ to $\mathrm{Z}$ & .181 & 0.122 & 0,303 \\
\hline $\mathrm{Y}$ to $\mathrm{Z}$ & .571 & - & .571 \\
\hline
\end{tabular}

\subsection{Structural Testing Results (Inner Model)}

Model struktual (inner model) is the relationship between the latent variables with each other latent variables. This test into a model research by looking at the multiple - square and significance levels each - each relationship. 
Table 3. Value coefficient of determination / multiple square

\begin{tabular}{ccc}
\hline Structural & multiple Square & P-value \\
\hline $\operatorname{zx} \rho 1$ & .654 & 0,000 \\
$\operatorname{zx} \rho 2$ & .181 & 0,002 \\
$\rho$ yx 1 & 0,753 & 0,004 \\
$\rho$ yx 2 & 0.214 & 0,000 \\
$\rho$ yz & .571 & 0,000 \\
$\rho$ yx 1 x 2 & .851 & 0,000 \\
$\operatorname{zx} \rho 1 \times 2$ & 0.632 & 0,000 \\
\hline
\end{tabular}

Based on the results of Table 3 to see multiple - square can be examined as the result of the following outputs:

- Internal factors influence the performance ( $\rho \mathrm{z}$ x 1) amounted to 0.654 (65.4\%);

- the influence of external factors on the performance ( $\rho z$ x 2) amounted to 0.181 (18.1\%);

- Internal factors influences on motivation ( $\rho y \times 1)$ amounted to 0,753 (75.3\%);

- the influence of external factors on motivation ( $\rho$ x $\mathrm{2}$ ) amounted to $0.214(21.4 \%)$;

- motivational influence on the performance ( $\rho y \mathrm{z})$ of 0.571 (57.1\%);

- $\quad$ internal and external factors influence the motivation ( $\rho y x 1 \times 2$ ) amounted to $0.851(85.1 \%)$

- the influence of internal and external factors on the performance ( $\rho z x 1 \times 2)$ amounted to $0.632(63.2 \%)$.

\section{Discussion}

The results of the analysis with the calculation method of Structural Equation Modelling (SEM) with the help of the program Analysis of Moment Structures (AMOS) Table 3 can be explained as follows:

1) The influence of internal factors have a positive influence on the performance significant Employees Variable civil service police Unit Riau province with path coefficient value of 0,654 and a P value of Value of 0,000 (less than 0.05). Based on the calculation that the influence of internal variables (X1) to performnce amounted to $65.4 \%$ and the influence of other factors amounted to $34.6 \%$.

2) Effect of external factors have a positive influence on the performance significant Employees Variable civil service police Unit Riau province with path coefficient value of 0,181 and a P value of 0.00 Value 2 (less than 0.05). Based on the calculation that the influence of external variables (X2) to performance by $18.1 \%$ and the influence of other factors amounted to $81.9 \%$.

3) The influence of motivational factors have a positive influence on the performance significant Employees Variable civil service police Unit use values Riau province with path coefficient of 0,571 and a $\mathrm{P}$ value of 0.000 Value (less than 0.05). Based on the calculation that influence motivation variable (Y) against performance of $57.1 \%$ and other $\mathrm{r}$ facto influence by $42.9 \%$.

4) Based on Table 3 is a value determinant coefficient (MultipleSquare) at 0,851 . This means that together the influence of internal factors variable (X1), external (X2), motivation (Y) on the performance of $85.1 \%$ and the remaining $14.9 \%$ is influenced by other factors not examined.

The study found the model verification test results and prove the theory that using SEM and programs Analysis of Moment Structures (AMOS). The advantage, among others; Amos can be understood as a path diagram shows the model specification and parameter estimates graphically in the diagram model lines. Diagrams lane is used as the model specification and the drawings of the path diagram can be imported into Word program.

Phase identification process variables and specification models are based on several theories related to motivation and performance. This process is related to relevant logic and the actual frame of mind.

Findings related to the description of the importance of internal factors, external factors, motivation and performance of employees in the organization and was instrumental in achieving corporate goals. It is evident from all of those factors included in the category is quite high and high.

Based on the simultaneous testing found that the differences in the model the influence of internal factors, external factors, motivation and performance of employees for temporary employees have a good model criteria. The criteria are fulfilled, namely Chi-square smaller, larger $\mathrm{R}^{2}$, and coefficient greater influence. Thus, the findings of the three models were estimated to have strength in terms of testing (power of test), capable of giving importance 
(meaningful) theoretically and statistically significant (statistically significant). Means that this model is open to the findings to be replicated and as a means of proving the theory of research results verification.

This study has the advantage because it uses empirical data collected during five months with cross-section. Application of scientific methods in sampling and respondent.

Internal factors given to temporary employees is very diverse both by type of work, employee expectations, salary, job satisfaction. Granting compensation for temporary staff differ in quantity and quality than permanent employees. Temporary staff tend to have less bargaining power (bargaining power) is good.

External factors such as type of work, work relationships, work performance, work atmosphere, has the particularity of each field according to the classification of jobs. Because of the diverse types of activities and services in the form of duty seems to have a lot of differences in the properties of the job, the burden of job tasks (TOR), and the risk of assuming. Associated with external factors work, employees will experience the psychological condition of the recognition given the importance of the task, is responsible experience, and knowledge of the work (Kreitner \& Kinicki, 2011, p. 265).

Motivational factors in the organization have a relatively dominant influence compared to other variables. This suggests that in order to manage the human resources potential in achieving organizational goals requires a strong motivation with different dimensions.

Factor performance of employees in medium and large organizations have different dimensions, especially the measurements that are categorical (ordinal). The response given by an employee does not remain sufficiently diverse as distributed on all the answer choices. This suggests that aspects of employee performance has an important role in the organization as a measure of productivity, efficiency, and effectiveness.

\section{Conclusions and Recommendations}

\subsection{Conclusion}

1). The influence of internal factors, external factors, motivation and performance of employees has significance for temporary employees who responded category is quite high and high

2). The influence of internal factors, external factors, motivation and employee performance is positive and significant, either partially or simultaneously.

3). Motivation of positive and significant effect on the performance of non-permanent employees.

4). Internal factors most dominant on the performance of temporary employees and other variables outside the model observed helped influence.

\subsection{Suggestion}

1). Need transparency and leadership in managing the Civil Service Police Unit in particular temporary employees for the performance of non-permanent employees can be maximized.

2). It should improve the leadership of the internal factors that include job satisfaction and salaries so that employees are not still able to work with good performance.

3). also external factors must be considered regarding the type of work, organizational structure and working atmosphere kondusip.

4). The existence of other variables outside the model that helped influence, the need for further study, especially the variables that have not been observed, such as work ethic, work culture, business climate, business expansion, government regulations, and technological advances.

\section{References}

Arikunto, S. (2007). Research Procedure A Practical Approach. Jakarta: Publisher Rineka Cipta.

Bacal, R. (2001). Performance Management.Empowering Employees, Improving Performance Through Feedback and Measuring Performance. Interpretation Surya Dharma and Yanuar Irwan. Moulds Second, Publisher PT. Gramedia Pustaka Utama, Jakarta.

Bernadin, H. J., \& Joyce, E. A. R. (1993). Human Resource Management: An Approach Experiental. New York: McGraw-Hill Series in Management.

Brian, C. (2004). HR / Benefits Outsourcing: Updating the Conventional Thinking. Employee Benefit Plan Review, 58(8), 18-21. ABI / INFORM Research.

Davis, K., \& Newtrom, J. W. (1995). Organization Behavior (Vol. 1, 7th ed.). 
Dess, G., \& Lumpkin, G. T. (2003). Strategic Management Creating Competitive Advantages. USA: McGraw-Hill Irwin.

Ghozali, I. (2009). Multivariate Analysis Application With PLS SEM Program. Semarang: Diponegoro University Publishers Agency.

Gibson, I., \& Donnelly. (1997). Organizational Behavior-Structure-Process, $1 \& 2(8)$. Binarupa Literacy, Jakarta.

Hair, J. F., Anderson, R. E., Latham, R., \& Black, W. C. (1998). Multivariate Data Analysis. New Jersey-Prentice Hall, Inc.

Hasibuan, M. (2009). Human resource management. Andi, Yogyakarta.

Kinicki. (2011). Organizational Behavior (5th ed.). New York: Irwin / McGraw-Hill Publishers.

Kusman, M. S. (1989). Managerial Fit and the Meaning of Working. Rijksuniversitet Gent-Belgie, School Voor Management (Unpublished dissertation).

Lum, L., Kervin, J., Clark, K., Reid, F., \& Sirola, W. (1998). Explaining nursing turnover intent: Job Satisfaction, Pay Satisfaction, or Organizational Commitment? Journal of Organizational Behavior, 19, 305-320. http://dx.doi.org/10.1002/(SICI)1099-1379(199805)19:3<305::AID-JOB843>3.0.CO;2-N

Luthans, F. (1995). Organizational Behavior. New York: McGraw-Hill Publishers.

Makrifah. (2009). Total Performance Scorecard, New Management Concepts to Achieve Performance with Integrity. Publisher PT. Gramedia Pustaka Utama, Jakarta.

Milkovich, G., \& John, W. B. (1991). Human Resource Management (6th ed.). USA.

Purwanto. (2006). Influence Factors of Job Satisfaction on Employee Performance. Publisher: Pabelan, Surakarta.

Robbins, \& Stephen. (2001). Organizational Behavior (9th ed.). United States of America: Printice-Hall International.

Siagian, \& Sondra. (2009). The theory of motivation and its application. Rineka Cipta, Jakarta.

Sunyoto, \& Danang. (2013). Theory, Questionnaires, and Organizational Behavior Data analysis process. PT. Intriguing book, Yogyakarta.

Wirawan. (2015). The Performance Evaluation of Human Resources: Theory, application and Research, Salemba Four, Jakarta.

Wood, J., Joseph, W., Rachid, M. Z., ...\& Osborn, R. N. (2001). Organizational Behaviour A Global Perspective (2nd ed.). John Wiley \& Sons Australia Ltd.

\section{Copyrights}

Copyright for this article is retained by the author(s), with first publication rights granted to the journal.

This is an open-access article distributed under the terms and conditions of the Creative Commons Attribution license (http://creativecommons.org/licenses/by/3.0/). 